\title{
Polysaccharide isolated from Triticum aestivum stimulates insulin release from pancreatic cells via the ATP-sensitive $\mathrm{K}^{+}$channel
}

\author{
SUN-HEE LEE ${ }^{1}$, SUNG-WON LIM ${ }^{1}$, YOUNG-MI LEE ${ }^{2}$, HOI-SEON LEE ${ }^{3}$ and DAE-KI KIM ${ }^{1}$ \\ ${ }^{1}$ Department of Immunology and Institute of Medical Sciences, Chonbuk National University Medical School, \\ Jeonju, Jeonbuk 561-180; ${ }^{2}$ Department of Oriental Pharmacy, College of Pharmacy and Whonkwang \\ Oriental Medicines Research Institute, Wonkwang University, Iksan, Jeonbuk 570-749; ${ }^{3}$ Faculty of \\ Biotechnology and Center for Agricultural Science and Technology, College of Agriculture and \\ Life Science, Chonbuk National University, Jeonju, Jeonbuk 561-756, Republic of Korea
}

Received November 30, 2011; Accepted January 18, 2012

DOI: $10.3892 / \mathrm{ijmm} .2012 .905$

\begin{abstract}
Traditional natural plants have been used throughout the world for their antidiabetic effects. The aim of the present study was to investigate the stimulating activity of a polysaccharide extract derived from T. aestivum sprout (TASP) on insulin secretion in vitro using the RIN-5F pancreatic $\beta$-cell line and rat pancreatic islets. In these experiments, TASP $(0.1$ to $2 \mathrm{mg} / \mathrm{ml}$ ) augmented glucose-stimulated insulin secretion in a dose-dependent manner in the presence of a stimulatory glucose concentration $(16.7 \mathrm{mM})$, but not of a basal concentration (1.1 mM). Although TASP failed to enhance the high $\mathrm{K}^{+}$-induced insulin secretion, the insulinotropic effect of TASP was significantly inhibited by diazoxide, an opener of ATP-sensitive $\mathrm{K}^{+}$ channel blocking insulin release. TASP potentiated the insulin secretion induced by other secretagogues, such as IBMX and tolbutamide. Moreover, glucose-derived blood insulin levels were significantly elevated by oral administration of TASP to mice, similarly to antidiabetic drugs. We also demonstrated that TASP significantly increased glucose-induced ${ }^{45} \mathrm{Ca}^{2+}$ uptake and proinsulin mRNA expression in rat islets. Overall, our results suggest that TASP has a stimulating effect on insulin secretion and production in pancreatic $\beta$-cells via $\mathrm{K}^{+}$channel closure and calcium influx. These results suggest that TASP may be useful as a candidate for the therapy of diabetes mellitus.
\end{abstract}

\section{Introduction}

Diabetes mellitus is a metabolic disease characterized by high blood glucose levels. Diabetic patients are classified into

Correspondence to: Dr Dae-Ki Kim, Department of Immunology and Institute of Medical Sciences, Chonbuk National University Medical School, Deokjin-dong, Deokjin-gu, Jeonju, Jeonbuk 561-756, Republic of Korea

E-mail:daekim@jbnu.ac.kr

Key words: Triticum aestivum, insulin secretion, pancreatic cells, calcium influx, diabetes mellitus
2 types; type 1 diabetes results from a deficiency in insulin secretion, whereas type 2 diabetes is a combination of insulin resistance and inadequate insulin secretion. Insulin is a hormone produced by $\beta$-cells in the pancreas after exposure to hyperglycemic conditions, and then acts to trigger tissues in the body to absorb glucose from the blood. A lack of insulin in the case of diabetes leads to severe dysfunction in the target organs as muscle, liver and adipose tissue $(1,2)$. The mechanisms of glucose-dependent insulin secretion have been examined by applying $\beta$-cells blockers (3). Uptake of glucose into $\beta$-cells leads to an elevation of ATP cellular level and blockage of the $\mathrm{K}^{+}$channels that results at the membrane depolarization, $\mathrm{Ca}^{2+}$ influx, and subsequent insulin secretion by exocytosis $(4,5)$.

In the pharmacotherapy of diabetes mellitus and insulinresistance, insulin is administered as the main treatment to reduce excess blood glucose levels. Also, sulphonylureas can be used to trigger insulin release from $\beta$-cells through opening of calcium channels (6). However, sulphonylureas have been prescribed with many restrictions due to side-effects, leading to hypoglycemia via the gradual $\beta$-cell destruction and impaired endothelial cell function (7). Most of the current drugs used for type 2 diabetes patients are not free from side effects and do not restore normal glucose homeostasis (8). Thus, the strategies of antidiabetic drug development focus on controlling glucose homeostasis with low toxicity even after extended use. Recent studies have been focused on herbal plants which are used traditionally as the source of foods, medicines, or nutritional supplements, for maintaining and treating diabetes.

A variety of polysaccharides from different biological sources has been postulated to enhance insulin release and sensitivity in diabetes. Since numerous bioactive polysaccharides isolated from herbal plants have been shown to have antidiabetic effects, they are becoming attractive materials for additional pharmaceutical products. Generally, the dietary supplements containing high levels of water soluble polysaccharides, such as soluble fiber and $\beta$-glucan, are effective in improving serum lipid levels, blood glucose levels, and insulin resistance (9-11). Current studies have shown that polysaccharides isolated from the traditional medical herbs have antihyperglycemic effect by insulin secreting activity 
$(12,13)$. We previously have shown that the aqueous extracts of Triticum aestivum sprout (TASP) attenuated blood glucose level in the streptozotocin (STZ)-induced diabetic mice, which is an animal model of human insulin-dependent type 1 diabetes (14). Some studies have shown that the aqueous extracts from wheat bran and wheatgrass improved postprandial glucose metabolism in patients with type 2 diabetes and diabetic rats (15-17). However, the hypoglycemic mechanisms of the aqueous extracts of TASP in diabetic mice remain completely unclear. Wheat is one of the most produced corps in the world, along with corn and rice. During the germination/sprouting stage, the synthesis of useful compounds, such as vitamins and phenolic compounds, occurs in the seeds. The germinated wheat leafs generally are called wheatgrass, in some European countries, USA and India, and consumed as a health food due to a rich source of soluble fibers, vitamins, antioxidants and minerals (18).

In the present study, according to evidence that plantderived polysaccharides have stimulatory effects on the insulin response $(19,20)$, we investigated the stimulatory effects of water soluble polysaccharide derived from TASP on insulin release from the pancreatic cells in vitro and in vivo. We also elucidated the involvement of the ATP-sensitive $\mathrm{K}^{+}$ channel and $\mathrm{Ca}^{2+}$ influx with TASP using the pancreatic cells and rat islets, which have been used for the study of insulin secretogogues.

\section{Materials and methods}

Cell culture. The RIN-5F cell line was purchased from the ATCC Global Bioresource Center (Manassas, VA). Cells were maintained in RPMI-1640 medium (Hyclone, Logan, UT) containing $10 \%$ fetal bovine serum (Hyclone) and $100 \mathrm{U} / \mathrm{ml}$ penicillin/streptomycin (Invitrogen, Carlsbad, CA) by transfer to new culture plates every 2 days. Male Wistar rats (9-10 weeks, 240-260 g body weight) were euthanized by inhalation of ether and cervical dislocation. The pancreas was dissected out and the islets of Langerhans were isolated by the collagenase digestion method (21). Isolated islets were collected in new tube and washed twice with Kreb's-Ringer bicarbonate (KRB) buffer $\left(115 \mathrm{mM} \mathrm{NaCl}, 4.7 \mathrm{mM} \mathrm{KCl}, 1.28 \mathrm{mM} \mathrm{CaCl}_{2}, 1.2 \mathrm{mM}\right.$ $\mathrm{KH}_{2} \mathrm{PO}_{4}, 1.2 \mathrm{mM} \mathrm{MgSO}$, $24 \mathrm{mM} \mathrm{NaHCO}, 1.1 \mathrm{mM}$ glucose, $0.25 \%$ bovine serum albumin; $\mathrm{pH} 7.4$ ), and preincubated for $1 \mathrm{~h}$ at $37^{\circ} \mathrm{C}$ under $5 \% \mathrm{CO}_{2}$ humidified air. For the experiments, all other reagents were purchased from Sigma-Aldrich (St. Louis, MO, USA).

Extraction and purification of TASP. TASP were provided from the National Institute of Crop Science (Jeonbuk, Korea) and dried using a freezer dryer. Water-soluble polysacchariderich extracts from TASP were isolated according to a method described previously (22). Briefly, the dried TASP (100 g) was macerated using $1000 \mathrm{ml}$ of distilled water for $15 \mathrm{~min}$ and extracted for $1 \mathrm{~h}$ at room temperature under continuous ultrasonic. The crude extract was filtered by Whatman grade no. 1 filter paper and precipitated with 5 volumes of ethanol. The precipitate was suspended in distilled water for removing protein by the Sevag method (23). To remove the Sevag's solution, the extract was precipitated by adding ethanol, washed with acetone and ethanol (yield $2.1 \mathrm{~g}$ ). The extract was further purified with DEAE Sephadex A-25 column $(0.15 \mathrm{M} \mathrm{NaCl}$ as the mobile phase) by high performance liquid chromatography (HPLC, Waters, Milford, MA) with an electrochemical detector (ELCD). After precipitation with ethanol for desalting, the main polysaccharide (TASP) was collected and dried completely using a rotary evaporator and a freeze dryer. The polysaccharide content was measured by the phenol-sulfuric acid method using D-glucose as the standard (24) and [(1-3) (1-4)]- $\beta$-D-glucan was by a mixed-linkage $\beta$-glucan assay kit (Megazyme Ltd., Wicklow, Ireland), which has been adapted for measurement of $\beta$-glucan in plant fiber products, according to a protocol provided from the manufacturer. The contents of total carbohydrates and non-starch polysaccharide were $98 \pm 1$ and $93 \pm 1 \%$, respectively. Neutral sugar composition analysis revealed that the extract was composed of glucose, mannose and galactose at a molar ratio of 1.4:1.0:2.1, respectively.

Cytotoxicity assay. Cell cytotoxicity assays were performed using the cell counting kit-8 (CCK-8) (Dojindo Molecular Technology, Inc., Rockville, MD). Cells (2.0x10 4 cells/well) were seeded in 96-well plates and incubated with conditioned RPMI-1640 medium at $37^{\circ} \mathrm{C}$ under $5 \% \mathrm{CO}_{2}$ atmosphere. After preincubation for $24 \mathrm{~h}$, the RIN-5F cells were cultured with or without compounds, and then $10 \mu \mathrm{l}$ of the CCK- 8 solution was added into each well for further incubated for $2 \mathrm{~h}$. The absorbance at $450 \mathrm{~nm}$ was measured using a microplate reader. Data are shown as the percentage of cell viability.

Insulin assay. The RIN-5F pancreatic cell line was used to evaluate the activity of insulin secretion. Cells $\left(2.0 \times 10^{5}\right.$ cells/ well) were seeded in the plate. After $24 \mathrm{~h}$, each well was washed twice with KRB buffer and then replaced with fresh KRB buffer containing 1.1 or $16.7 \mathrm{mM}$ glucose with or without various reagents or the extract. After incubation for $60 \mathrm{~min}$, the medium was collected and centrifuged to remove the cells. The supernatant was used for insulin measurement and the insulin content was determined by an enzyme link immunosorbent assay (ELISA) kit obtained from Shibayagi Co. (Ishihara, Japan).

${ }^{45} \mathrm{Ca}^{2+}$ uptake assay. To examine the involvement of calcium influx, the $\mathrm{Ca}^{2+}$ uptake assay was performed in rat islets as described previously (25). Briefly, the isolated 10 rat islets were seeded in 96-well plates and then incubated in KRB buffer containing a radioactive ${ }^{45} \mathrm{Ca}^{2+}(5 \mu \mathrm{Ci} / \mathrm{ml}$, American Radiolebeled Chemicals, Inc.; St. Louis, MO) for $10 \mathrm{~min}$. To remove the free isotope, cells were washed with isotopefree buffer, and then lysed in $80 \mu \mathrm{l} /$ well lysis buffer $(50 \mathrm{mM}$ Tris-HCl, pH 7.5, $150 \mathrm{mM} \mathrm{NaCl}, 1 \%$ Triton X-100, 0.1\% SDS, $5 \mathrm{mM}$ EDTA) for $30 \mathrm{~min}$. The solubilized cell extracts were mixed with equal volume of Optiphase Supermix scintillation cocktail (Perkin-Elmer, Boston, MA) and counted in a liquid scintillation counter (Packard Tri-Carb 2900TR).

In vivo experiments. Male C57BL/6 mice (8-weeks-old) were purchased from Chungang Experimental Animal, Inc. (Seoul, Korea) and acclimated for 4 weeks prior to use. All mice were housed under standard conditions at $22 \pm 1^{\circ} \mathrm{C}$ with humidity of $50 \pm 10 \%$. All procedures were carried out in strict according to the guidelines established by the University's Committee for 


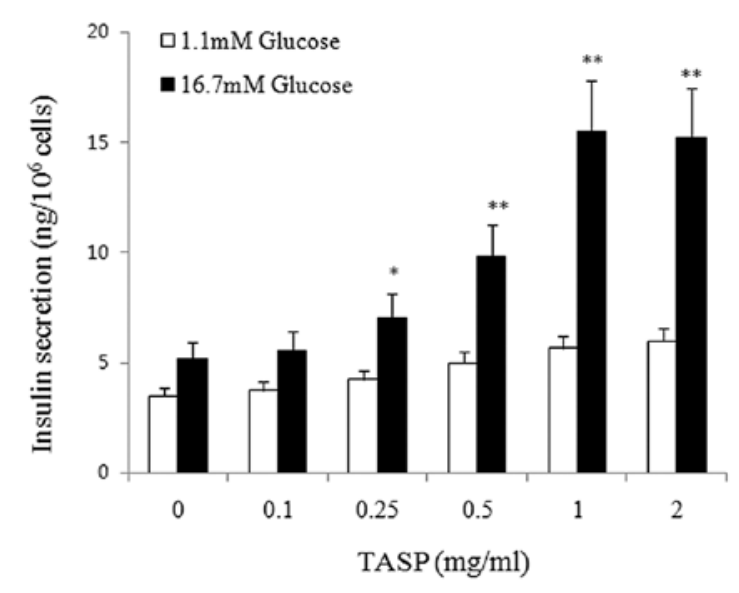

Figure 1. Effects of TASP on glucose-stimulated insulin secretion from RIN-5F pancreatic cells. Cells were incubated with various concentration of TASP for $1 \mathrm{~h}$ to induce insulin secretion. Glucose was used as the control (negative and positive, respectively) for basal $(1.1 \mathrm{mM})$ and hyperglycemic $(16.7 \mathrm{mM})$ conditions. Values are represented as the means \pm SEM of 5 replicate experiments in each group. ${ }^{*} \mathrm{P}<0.05,{ }^{* *} \mathrm{P}<0.01$ compared with the control group of $16.7 \mathrm{mM}$ glucose.

Animal Experiments regarding the use and care of laboratory animals. Mice were fasted for $18 \mathrm{~h}$ before the experiments. For the glucose tolerance test, glucose $(2 \mathrm{~g} / \mathrm{kg})$ was given orally to fasted mice with or without TASP, which was administered orally $30 \mathrm{~min}$ before glucose challenge. Blood samples were obtained from the tail vein of mice before and 30,60, 90, 120, 150 and 180 min after glucose challenge. Blood glucose levels were determined at all time points using the Accu-Chek blood glucose meter (Roche Diagnostics GmbH, Mannheim, Germany). The serum insulin levels were measured in blood samples obtained from the orbital sinus $60 \mathrm{~min}$ after glucose challenge by an ELISA kit.

RNA isolation and real-time RT-PCR. Total-RNA was extracted from rat islets by TRIzol reagent (Invitrogen), precipitated with isopropanol. RNA $(1 \mu \mathrm{g})$ was used for synthesizing fist-strand cDNA using the iScript cDNA synthesis kit (Bio-Rad, Hercules, CA). The specific primers of insulin and $\beta$-actin used for PCR were designed through the Primer Express Software (Applied Biosystems, Foster City, CA); insulin, forward primer, 5'-TCT TCA GAC CTT GGC ACT GGA-3' and reverse primer, 5'-AGA TGC TGG TGC AGC ACT GAT-3'; $\beta$-actin, forward primer, 5'-ACG AGG CCC AGA GCA AGA-3' and reverse primer, 5'-TTG GTT ACA ATG CCG TGT TCA-3'. $\beta$-actin was used as a control gene. The PCR reactions were performed on 384-well plates using the ABI 7900HT Fast Real-Time PCR System (Applied Biosystems).

Statistical analysis. All values are represented as the mean \pm SEM. The statistical significance of the experiments was evaluated by the one-way ANOVA test. $\mathrm{P}<0.05$ was considered to be significant.

\section{Results}

The effect of TASP on insulin secretion in RIN-5F cells. We investigated the stimulatory effect of water soluble polysaccharide-rich TASP on insulin secretion in vitro to estimate its

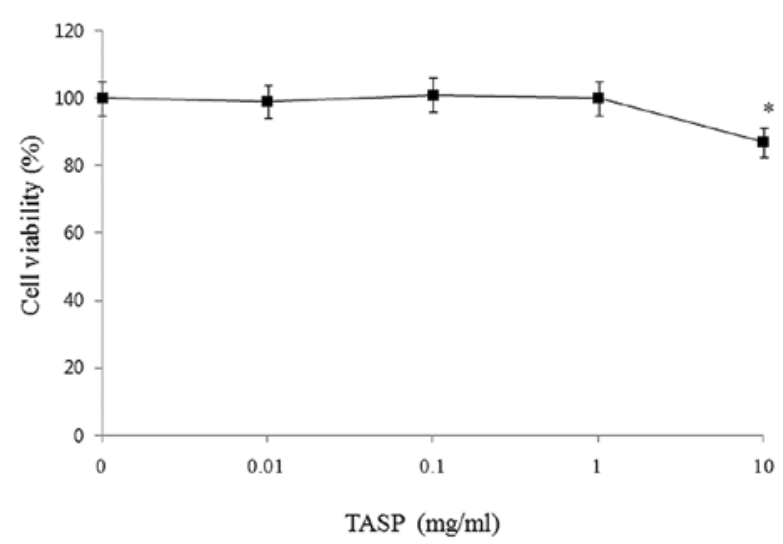

Figuse 2. Effects of TASP on the cytotoxicity in RIN-5F pancreatic cells. Cells were incubated with various concentration of TASP for $24 \mathrm{~h}$ in the presence of $16.7 \mathrm{mM}$ glucose. Cell viability was measured using the CCK8 cell proliferation kit. Values are represented as the means \pm SEM of 5 replicate experiments in each group. ${ }^{*} \mathrm{P}<0.05$, compared with a control group without TASP.

antidiabetic potential. The activity was estimated based on the insulin levels released from RIN-5F cells under both basal and hyperglycemic conditions, which contain 1.1 and $16.7 \mathrm{mM}$ glucose, respectively. As shown in Fig. 1, the insulin secretion was augmented when the glucose concentration was increased from 1.1 to $16.7 \mathrm{mM}$. Although TASP in the presence of $1.1 \mathrm{mM}$ glucose did not induce the insulin secretion from the cells, exposure to TASP $(0.1-2 \mathrm{mg} / \mathrm{ml})$ in the presence of $16.7 \mathrm{mM}$ glucose induced a significant increase in insulin secretion in a concentration-dependent manner $(\mathrm{P}<0.01)$. The maximum activity was observed with $1 \mathrm{mg} / \mathrm{ml} \mathrm{TASP}$. Indeed, at $16.7 \mathrm{mM}$ glucose, TASP induced a 2.7-fold increase in the insulin secretion compared to that without TASP, whereas TASP in $1.1 \mathrm{mM}$ glucose showed a lower activity. Toxicity profiles of TASP in the cells were determined at the $0.01-10 \mathrm{mg} / \mathrm{ml}$ range of TASP concentration by a cell proliferation assay (Fig. 2). The incubation period for the induction of insulin secretion was insufficient to detect cytotoxicity. Therefore, the cultures were incubated for $24 \mathrm{~h}$. TASP did not show apparent cytotoxicity up to $5 \mathrm{mg} / \mathrm{ml}$, indicating that the activities of TASP on insulin secretion were not due to their toxicity.

The effect of TASP on insulin secretion in the presence of $K^{+}$. We examined the influence of membrane depolarization using a high concentration of $\mathrm{K}^{+}$on the insulin secretion induced by TASP (Fig. 3). As shown in Fig. 3A, a depolarizing concentration of $\mathrm{KCl}(30 \mathrm{mM})$ significantly augmented the insulin secretion at both low and high glucose concentrations in the absence of TASP $(\mathrm{P}<0.01)$. Indeed, exposure to high $\mathrm{K}^{+}$in the presence of 1.1 and $16.7 \mathrm{mM}$ glucose induced a 3.3- and 2.6-fold increase in insulin release, respectively, whereas the combination of TASP $(1 \mathrm{mg} / \mathrm{ml})$ with $\mathrm{K}^{+}$did not show a significant increase in $\mathrm{KCl}$-induced insulin secretion. Next, to examine the involvement of $\mathrm{K}^{+}$channel closure in cell membranes on the increase in insulin secretion by TASP, we used diazoxide $(300 \mu \mathrm{M})$, which is a well known opener of the $\mathrm{K}^{+}$-ATP channel (26). As shown in Fig. 3B, treatment with diazoxide induced a prominent inhibition of insulin release at all conditions. Indeed, incubation with diazoxide in the presence of $16.7 \mathrm{mM}$ glucose induced a significant decrease (61\%) in TASP-induced insulin 

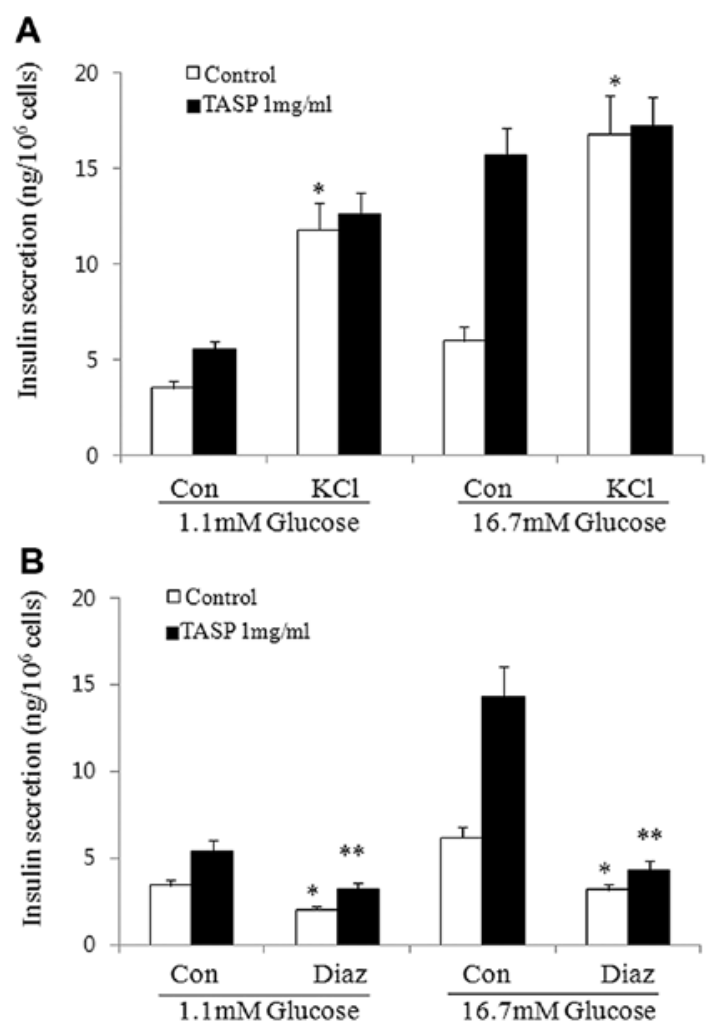

Figure 3. Effect of TASP on insulin secretion from RIN-5F pancreatic cells in the presence of (A) $\mathrm{KCl}$ and (B) diazoxide. Cells were incubated with or without TASP $(1 \mathrm{mg} / \mathrm{ml})$ for $1 \mathrm{~h}$ in the presence of 1.1 and $16.7 \mathrm{mM}$ glucose. (A) The stimulating activity of $\mathrm{KCl}(20 \mathrm{mM})$ on TASP-induced increase in insulin secretion was examined. ${ }^{*} \mathrm{P}<0.01$ compared without $\mathrm{KCl}$ at the same glucose condition. (B) The inhibitory action of diazoxide (Diaz, $0.3 \mathrm{mM}$ ) on TASP-induced increase in insulin secretion was assessed. ${ }^{*} \mathrm{P}<0.05,{ }^{* * *} \mathrm{P}<0.01$ compared without diazoxide at the same condition. All values are represented as the means \pm SEM of 5 replicate experiments in each group.

release $(\mathrm{P}<0.01)$. In addition, the inhibitory effect of diazoxide indicates that the stimulation of insulin secretion by TASP was not a consequence of damage to the cells.

Effect of TASP in the presence of insulin secretagogues. We examined the interaction of TASP with insulin secretagogues, such as L-alanine, 3-isobutyl-1-metylxantine (IBMX, a phosphodiesterase inhibitor), and tolbutamide (an inhibitor of $\beta$-cell $\mathrm{K}^{+}$-ATP channels), on glucose-induced insulin release (7,27,28). As shown in Fig. 4, exposure to L-alanine (10 mM), IBMX (25 mM) or tolbutamide $(0.2 \mathrm{mM})$ induced 2.1-, 1.3- or 2.0 -fold increases in insulin release in the presence of $1.1 \mathrm{mM}$ glucose (Fig. 4A), and 2.7-, 1.3- or 3.7-fold increases in the presence of $16.7 \mathrm{mM}$ glucose (Fig. 4B), respectively. TASP $(1 \mathrm{mg} / \mathrm{ml})$ significantly enhanced their activities on insulin secretion $(\mathrm{P}<0.05, \mathrm{P}<0.01)$. The synergistic effect of TASP on the insulin secretion was observed by combination with L-alanine, IBMX or tolbutamide in the presence of $1.1 \mathrm{mM}$ glucose (Fig. 4A). However, although L-alanine and IBMX stimulated the increase in insulin secretion from the cells, their combination with TASP showed no synergistic effect in the presence of $16.7 \mathrm{mM}$ glucose (Fig. 4B). Tolbutamide also revealed an insignificant increase in TASP-stimulated insulin secretion in the presence of $16.7 \mathrm{mM}$ glucose, compared to that with TASP alone. The results suggest that the stimulatory
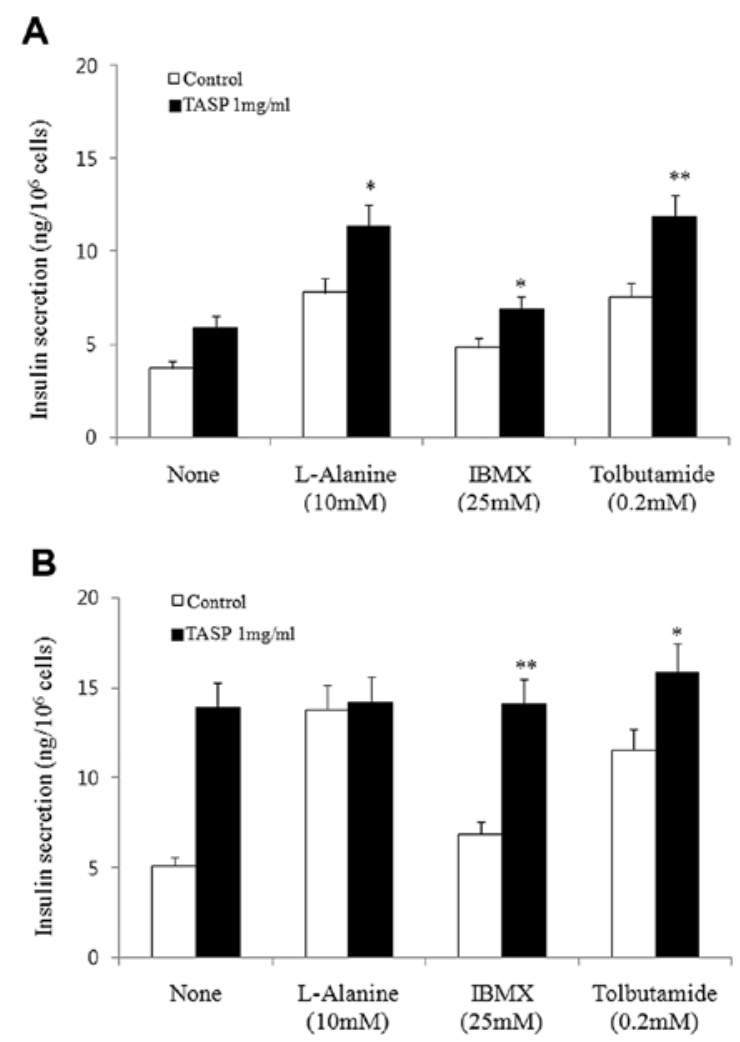

Figure 4. Effect of L-alanine, IBMX, and tolbutamide on TASP-induced insulin secretion from RIN-5F pancreatic cells. Cells were incubated with L-alanine $(10 \mathrm{mM})$, IBMX $(25 \mathrm{mM})$, or tolbutamide $(0.2 \mathrm{mM})$ for $1 \mathrm{~h}$ in the presence or absence of TASP $(1 \mathrm{mg} / \mathrm{ml})$. (A) Low glucose $(1.1 \mathrm{mM})$ was used for basal glucose condition, and (B) high glucose $(16.7 \mathrm{mM})$ was for hyperglycemic conditions. Values are represented as the means \pm SEM of 5 replicate experiments in each group. ${ }^{*} \mathrm{P}<0.05,{ }^{* *} \mathrm{P}<0.01$ compared without TASP at the same condition.

Table I. Effect of TASP on ${ }^{45} \mathrm{Ca}^{2+}$ uptake into the isolated rat pancreatic islets in the presence of 1.1 and $16.7 \mathrm{mM}$ of glucose.

\begin{tabular}{lcc}
\hline \multirow{2}{*}{ Glucose $(\mathrm{mM})$} & \multicolumn{2}{c}{${ }^{45} \mathrm{Ca}^{2+}$ uptake (fmole) } \\
\cline { 2 - 3 } 1.1 & Control & TASP \\
16.7 & $12,732 \pm 1,772$ & $18,899 \pm 1,558^{\mathrm{a}}$ \\
& $21,686 \pm 2,726$ & $43,351 \pm 2,874^{\mathrm{a}}$
\end{tabular}

The isolated rat islets was incubated with or without TASP $(1 \mathrm{mg} /$ $\mathrm{ml}$ ) for $30 \mathrm{~min}$ in the presence of 1.1 and $16.7 \mathrm{mM}$ of glucose. Values are presented as the means \pm SEM of 5 replicate experiments in each group. ${ }^{\mathrm{P}}<0.01$, compared without TASP at the same glucose condition.

effect of TASP may be similar to its mechanism of inducing insulin secretion.

Effect of TASP on $\mathrm{Ca}^{2+}$-uptake and proinsulin mRNA expression. Some insulin secretagogues increase insulin secretion and expression by allowing the extracellular $\mathrm{Ca}^{2+}$ flux into $\beta$-cells (25). We therefore examined whether TASP influences $\mathrm{Ca}^{2+}$ uptake and insulin expression in the pancreatic islets isolated from rats. To assess the activity of ${ }^{45} \mathrm{Ca}^{2+}$ uptake, the isolated rat islets were stimulated with or without TASP $(1 \mathrm{mg} / \mathrm{ml})$ in 


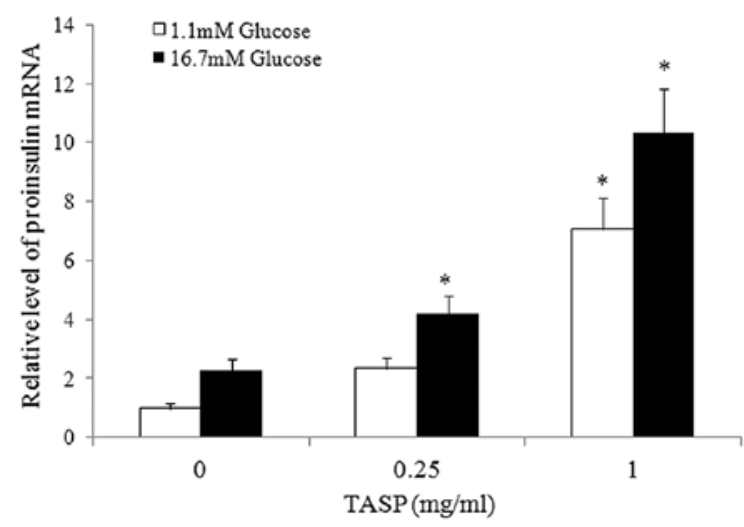

Figure 5. Effect of TASP on the level of proinsulin mRNA in the rat pancreatic islets. The isolated rat islets were incubated with RPMI-1640 medium containing 1.1 or $16.7 \mathrm{mM}$ glucose for $18 \mathrm{~h}$ in the presence or absence of TASP $(0.25$ and $1 \mathrm{mg} / \mathrm{ml})$, and the level of proinsulin mRNA was determined by real-time PCR. Values are presented as relative proinsulin mRNA compared with that of a control in the presence of $1.1 \mathrm{mM}$ glucose. ${ }^{*} \mathrm{P}<0.01$ compared with a control without TASP.

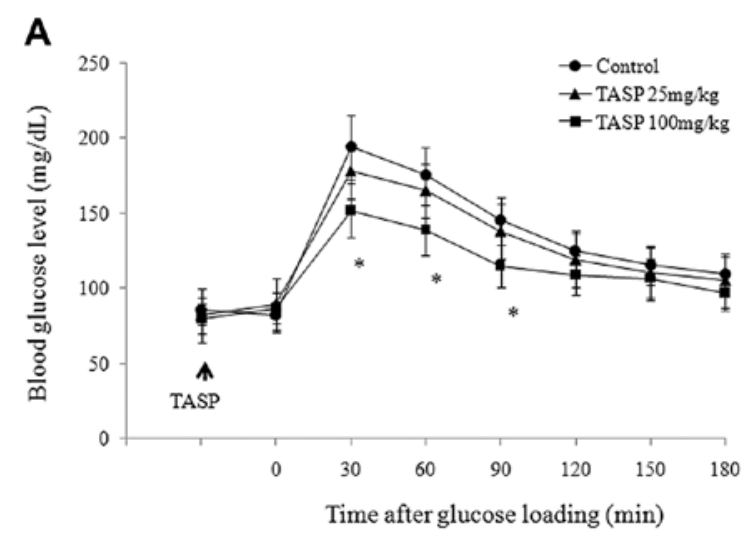

B

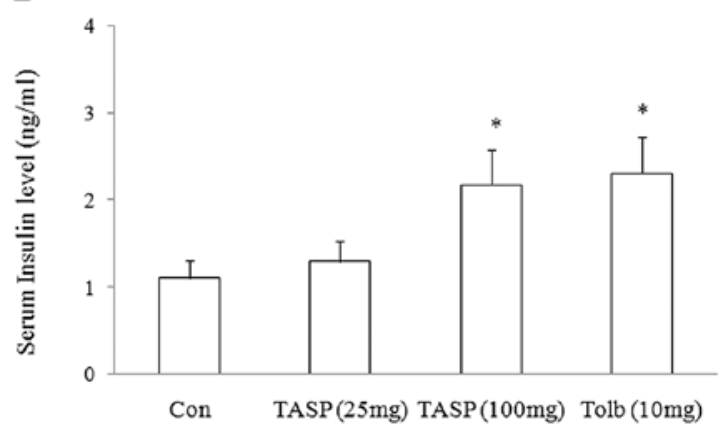

Figure 6. Effect of TASP on the levels of (A) blood glucose and (B) serum insulin in fasted normal mice. (A) Blood glucose levels were measured in 30 min intervals before and after glucose challenge. (B) Serum insulin levels were measured $1 \mathrm{~h}$ after glucose challenge. TASP (25 and $100 \mathrm{mg} / \mathrm{kg}$ ) and tolbutamide (Tolb, $10 \mathrm{mg} / \mathrm{kg}$ ) were adminstrated $30 \mathrm{~min}$ before glucose challenge. Values are represented as mean \pm SEM ( $n=6$ in each groups). ${ }^{*} \mathrm{P}<0.05$ as compared with negative control

the presence of 1.1 and $16.7 \mathrm{mM}$ glucose. As shown in Table I, ${ }^{45} \mathrm{Ca}^{2+}$ uptake was augmented by 1.7 -fold when the glucose concentration was increased from 1.1 to $16.7 \mathrm{mM}$. Stimulation with TASP significantly potentiated the level of glucosedependent $\mathrm{Ca}^{2+}$-uptake $(\mathrm{P}<0.01)$. Indeed, the increase of $\mathrm{Ca}^{2+}$ influx induced by TASP was 1.48 - and 2.0-fold in the presence of 1.1 and $16.7 \mathrm{mM}$ glucose, respectively. Next, to measure the level of proinsulin mRNA using real time-PCR, the islets were stimulated with or without TASP $(0,0.25,1 \mathrm{mg} / \mathrm{ml})$ for $18 \mathrm{~h}$ in the presence of 1.1 and $16.7 \mathrm{mM}$ glucose. As shown in Fig. 5, the high glucose condition $(16.7 \mathrm{mM})$ resulted in a 2.3-fold increase in the level of proinsulin mRNA compared to the basal glucose condition (1.1 mM). Moreover, TASP significantly augmented proinsulin mRNA expression in the islets in a concentration-dependent manner $(\mathrm{P}<0.01)$. Indeed, the maximal level of proinsulin mRNA was observed in the islets stimulated with $1 \mathrm{mg} / \mathrm{ml}$ of TASP, revealing a 4.4-fold increase in the presence of $16.7 \mathrm{mM}$ glucose.

Effect of TASP on the levels of blood glucose and serum insulin in vivo. We examined the effects of TASP on blood glucose regulation and insulin secretion in vivo by the glucose tolerance test. TASP (25 and $100 \mathrm{mg} / \mathrm{kg}$ ) was administered orally $30 \mathrm{~min}$ before glucose challenge in fasted normal mice. As shown in Fig. 6A, the blood glucose level reached a peak 30 min after glucose challenge and decreased in a timedependent manner. TASP showed a hypoglycemic effect in glucose challenged-mice. Indeed, administration of $100 \mathrm{mg} / \mathrm{kg}$ TASP significantly reduced the blood glucose levels elevated after glucose challenge $(\mathrm{P}<0.05)$. Moreover, TASP $(100 \mathrm{mg} / \mathrm{kg})$ induced a significant increase in the levels of blood insulin in glucose-loaded mice compared to a negative control $(\mathrm{P}<0.05)$. The stimulatory activity of TASP was comparable to that of tolbutamide, which was used as a positive control. These results indicate that TASP may have an antihyperglycemic effect by potentiating glucose-induced insulin release.

\section{Discussion}

Traditional plant treatments have been used throughout the world for the therapy of diabetes mellitus. We previously demonstrated that the aqueous extract of TASP has a hypoglycemic effect in diabetic mice through the increase in serum insulin concentration (14). In this study, we demonstrated that TASP potentially has a stimulatory effect on glucose-induced insulin secretion in vitro and in vivo and in a dose-dependent manner. The antidiabetic effects of TASP are similar to those of well known insulin secretagogues, such as tolbutamide. In addition, TASP significantly enhanced on the expression of proinsulin mRNA in a glucose-dependent response.

Most insulin secretagogues stimulate insulin secretion from the pancreatic $\beta$-cells through depolarization of the plasma membrane and activation of $\mathrm{Ca}^{2+}$-dependent processes (4). This is established from the mechanism of action of drugs that are used for therapy of type 2 diabetes patients. It has been well known that tolbutamide stimulates insulin secretion from islets, principally by inhibiting ATP-sensitive $\mathrm{K}^{+}$channels in the cell membrane, consequently causing a membrane depolarization and an activation of voltage-gated $\mathrm{Ca}^{2+}$ influx $(26,29)$. It has been known that diazoxide is a compound preventing the closure of voltage $\mathrm{K}^{+}$-ATP channels and blocking insulin secretions (30).

In the present study, we observed that diazoxide remarkably suppressed the stimulating activity of TASP in glucose-induced insulin release. The results suggest that the ability of TASP to 
stimulate insulin secretion may be mediated by depolarization of the cell membrane and consequent closure of $\mathrm{K}^{+}$-ATP channels. Interestingly, TASP significantly increased the insulin secretion induced by other insulin secretagogues, such as the inhibitor of cAMP phosphodiesterase (IBMX) and antidiabetic drugs in the presence of basal glucose concentration. However, they failed to potentiate the insulin-releasing effect of TASP in the hyperglycemic condition, indicating the possibility that TASP may have various actions to induce insulin secretion from $\beta$-cells.

The calcium entry plays a key role in the insulinotropic activity of pancreatic $\beta$-cells $(25,31)$. Thus, we estimated the involvement of calcium by TASP in conditions designed for $\mathrm{Ca}^{2+}$ influx into $\beta$-cells. Indeed, TASP induced the significant increase in the level of $\mathrm{Ca}^{2+}$ uptake into the isolated rat islets in the presence of stimulatory glucose concentrations, revealing that the insulinotropic action induced by TASP is dependent on extracellular calcium flux. The additional involvement of calcium entry was evidenced by the inhibition of the insulin releasing effect caused by the removal of calcium. Interestingly, TASP augmented the expression of proinsulin mRNA in pancreatic $\beta$-cells. Although tolbutamide belonging to the sulfonylureas group has been used successfully as an antidiabetic drug for type 2 diabetes due to its property to accelerate the insulin secretion in the pancreas, it has never used in the treatment of type 1 diabetes due to its ineffective production of insulin (7). In contrast, TASP has the effective properties of stimulating insulin production as well as insulin secretion, suggesting that TASP may be useful as a potent antidiabetic material for the therapy of both type 1 and 2 diabetes

The insulin secretion effects have been reported in a number of studies using aqueous extracts of plants. Most of the plants with antidiabetic properties have been found to contain compounds such as glycosides, alkaloids, and flavonoids, showing potentially antihyperglycemic action (32-36), but most of them still need proper scientific evaluation. Indeed, the alkaloids and saponins have been reported to inhibit glucose uptake, whereas the flavonoids could protect various cell types from oxidative stress-mediated cell injury $(37,38)$. Another research has been reported that glycosides could stimulate insulin secretion as well. The polysaccharide compounds derived from algae extracts and Agaricus blazei enhanced the insulin secretion in vitro in the pancreatic $\beta$-cells $(19,20)$. Oat bran-derived non-starch polysaccharides acted as an active ingredient decreasing the postprandial hyperglycemic response in humans with type 2 diabetes (39). The levan polysaccharide also was efficient in inhibiting hyperglycemia and oxidative stress induced by diabetes (40). A similar result was observed in humans after eating $\beta$-glucan-enriched breads (41). The polysaccharides obtained from the tuberous root of Liriope spicata had the hypoglycemic effects in streptozotocin-induced type 2 diabetic mice (42). These substances may be responsible for the antidiabetic effects of TASP observed in this study.

In conclusion, the present study demonstrated that TASP significantly potentiated the insulin secretion and production from the pancreatic $\beta$-cells in a glucose-dependent manner. The insulin secreting activity of TASP may involve the closure of $\mathrm{K}^{+}$-ATP channels and the enhancement of the calcium influx through voltage-dependent $\mathrm{Ca}^{2+}$ channels, like tolbutamide, which is an antidiabetic drug. Thus, our results indicate that TASP should be regarded as a potent antihyperglycemic agent with the property of accelerating the secretion and production of insulin in the pancreas. TASP has been commonly used as a nutritional supplement controlling diabetes mellitus and its complications. Therefore, further studies are necessary to elucidate the precise mechanisms of the antidiabetic action of TASP, such as insulin signaling, $\beta$-cell function, and glucose absorption and metabolism.

\section{Acknowledgements}

This study was supported by a grant from the Korea Institute of Planning and Evolution for Technology of Food, Agriculture, Forestry and Fisheries (108156-03-SB010).

\section{References}

1. Beardsall K, Yuen K, Williams R and Dunger D: Applied physiology glucose control. Curr Paediatr 13: 543-548, 2003.

2. Ferrer JC, Favre C, Gomis RR, Fernández-Novell JM, et al: Control of glycogen deposition. FEBS Lett 546: 127-132, 2003.

3. Herrington J, Zhou YP, Bugianesi RM, et al: Blockers of the delayed-rectifier potassium current in pancreatic beta-cells enhance glucose-dependent insulin secretion. Diabetes 55: 1034-1042, 2006.

4. Stumvoll M, Goldstein BJ and van Haeften TW: Type 2 diabetes: principles of pathogenesis and therapy. Lancet 365: 1333-1346, 2005.

5. Yang SN and Berggren PO: $\beta$-cell $\mathrm{CaV}$ channel regulation in physiology and pathophysiology. Am J Physiol Endocrinol Metab 288: 16-28, 2005.

6. Geng X, Li L, Bottino R, et al: Antidiabetic sulfonylurea stimulates insulin secretion independently of plasma membrane KATP channels. Am J Physiol Endocrinol Metab 293: 293-301, 2007.

7. Del-Prato S and Pulizzi N: The place of sulfonylureas in the therapy for type 2 diabetes mellitus. Metabolism 55: 20-27, 2006.

8. Rang HP, Dale MM and Rittar JM: The endocrine system pharmacology. In: Pharmacology. Longman Group Ltd., London. pp504-508, 1991.

9. Liu S: Intake of refined carbohydrates and whole grain foods in relation to risk of type 2 diabetes mellitus and coronary heart disease. J Am Coll Nutr 21: 298-306, 2002.

10. Hallfrisch J, Facn and Behall KM: Mechanisms of the effects of grains on insulin and glucose responses. J Am Coll Nutr 19 (Suppl 3): S320-S325, 2000.

11. Nandini CD, Salimath PM and Sambaiah K: Effect of dietary fibres on constituents of complex carbohydrates in streptozotocin induced diabetic rat tissues. Mol Cell Biochem 236: 133-138, 2002.

12. Dahech I, Belghith KS, Hamden K, Feki A, Belghith H and Mejdoub H: Antidiabetic activity of levan polysaccharide in alloxan-induced diabetic rats. Int J Biol Macromol 49: 742-746, 2011.

13. Hu F, Li X, Zhao L, Feng S and Wang C: Antidiabetic properties of purified polysaccharide from Hedysarum polybotrys. Can J Physiol Pharmacol 88: 64-72, 2010.

14. Lee SH, Lee YM, Lee HS and Kim DK: Anti-oxidative and anti-hyperglycemia effects of Triticum aestivum wheat sprout water extracts on the streptozotocin-induced diabetic mice. Kor $\mathbf{J}$ Pharmacogn 40: 408-414, 2009.

15. Giacco R, Brighenti F, Parillo M, et al: Characteristics of some wheat-based foods of the Italian diet in relation to their influence on postprandial glucose metabolism in patients with type 2 diabetes. Br J Nutr 85: 33-40, 2001.

16. Vaaler S, Hanssen KF, Dahl-Jørgensen K, Frølich W, Aaseth J, Odegaard B and Aagenaes O: Diabetic control is improved by guar gum and wheat bran supplementation. Diabet Med 3: 230-233, 1986.

17. Eddouks M, Maghrani M and Michel JB: Hypoglycaemic effect of Triticum repens P. Beauv. in normal and diabetic rats. J Ethnopharmacol 102: 228-232, 2005.

18. Nagaoka H: Treatment of germinated wheat to increase levels of GABA and IP6 catalyzed by endogenous enzymes. Biotechnol Prog 21: 405-410, 2005. 
19. Kim YW, Kim KH, Choi HJ and Lee DS: Anti-diabetic activity of beta-glucans and their enzymatically hydrolyzed oligosaccharides from Agaricus blazei. Biotechnol Lett 27: 483-487, 2005.

20. Zhang D, Fujii I, Lin C, et al: The stimulatory activities of polysaccharide compounds derived from algae extracts on insulin secretion in vitro. Biol Pharm Bull 31: 921-924, 2008.

21. Nielsen DA, Welsh M, Casadaban MJ and Steiner DF: Control of insulin gene expression in pancreatic beta-cells and in an insulinproducing cell line, RIN-5F cells. I. Effects glucose and cyclic AMP on the transcription of insulin mRNA. J Biol Chem 260: 13585-13589, 1985.

22. Luo AX, He XJ, Zhou SD, Fan YJ, He T and Chun Z: In vitro antioxidant activities of a water-soluble polysaccharide derived from Dendrobium nobile L. Extracts. Int J Biol Macromol 45: 359-363, 2009

23. Staub AM: Removal of proteins: Sevag method. Methods Carbohydr Chem 5: 5-6, 1965.

24. Dubois M, Gilles KA, Hamilton JK, Rebers PA and Smith F: Colorimetric method for determination of sugars and related substances. Anal Chem 28: 350-356, 1956.

25. Herchuelz A and Malaisse WJ: Regulation of calcium fluxes in pancreatic islets: association between calcium and insulin release. J Physiol 283: 409-424, 1978.

26. Trube G, Rorsman P and Ohno-Shosaku T: Opposite effects of tolbutamide and diazoxide on the ATP-dependent $\mathrm{K}^{+}$channel in mouse pancreatic beta-cells. Pflugers Arch 407: 493-499, 1986.

27. Sharp GWG: The adenylate cyclase-cyclic AMP system in islets of Langerhans and its role in the control of insulin release. Diabetologia 16: 287-297, 1979.

28. Leibowitz MD, Biswas C, Brady EJ, et al: A novel insulin secretagogue is a phosphodiesterase inhibitor. Diabetes 44: 67-74, 1995.

29. Thams P, Anwar RM and Capito K: Glucose triggers proteins kinase A-dependent insulin secretion in mouse pancreatic islets through activation of the $\mathrm{K}^{+}$-ATP channel-dependent pathway. Eur J Endocrinol 152: 617-677, 2005.

30. Grill V, Radtke M, Qvigstad E, Kollind M and Björklund A: Beneficial effects of K-ATP channel openers in diabetes: an update on mechanisms and clinical experiences. Diabetes Obes Metab 11: 143-148, 2009.

31. Hellman B, Sehlin J and Taljedal IB: Calcium and secretion: distinction between two pools glucose-sensitive calcium in pancreatic islets. Science 24: 1421-1423, 1976.
32. Gireesh G, Thomas SK, Joseph B and Paulose CS: Antihyperglycemic and insulin secretory activity of Costus pictus leaf extract in streptozotocin-induced diabetic rats and in vitro pancreatic islet culture. J Ethnopharmacol 123: 470-474, 2009.

33. Latha M, Pari L, Sitasawad S and Bhonde R: Insulin-secretagogue activity and cytoprotective role of the traditional antidiabetic plant Scopariadulcis (sweet broom weed). Life Sci 75: 2003-2014, 2004.

34. Liu B, Asare-Anane H, Al-Romaiyan A, Huang G, Amiel SA, Jones PM and Persaud SJ: Characterization of the insulinotropic activity of an aqueous extract of Gymnemasylvestre in mouse beta-cells and human islets of Langerhans. Cell Physiol Biochem 23: 125-132, 2009.

35. Sezik E, Aslan M, Yesilada E and Ito S: Hypoglycemic activity of Gentiana olivieri and isolation of the active constituent through bioassay-directed fractionation techniques. Life Sci 76: 1223-1238, 2005.

36. Souza A, Mbatchi B and Herchuelz A: Induction of insulin secretion by an aqueous extract of Tabernanhte iboga Baill. (Apocynaceae) in rat pancreatic islets of Langerhans. J Ethnopharmacol 133: 1015-1020, 2011

37. Ardestani A and Yazdanparast R: Flavonoids as potential therapeutic agents for type 1 diabetes. Med Hypotheses 69: 955-956, 2007.

38. Eidi A, Eidi M and Sokhteh M: Effect of fenugreek (Trigonella foenumgraecum $\mathrm{L}$ ) seeds on serum parameters in normal and streptozotocin-induced diabetic rats. Nutr Res 27: 728-733, 2007.

39. Tapola N, Karvonen H, Niskanen L, Mikola M and Sarkkinen E: Glycemic responses of oat bran products in type 2 diabetic patients. Nutr Metab Cardiovasc Dis 15: 255-261, 2005.

40. Dahech I, Belghith KS, Hamden K, Feki A, Belghith H and Mejdoub H: Oral administration of levan polysaccharide reduces the alloxan-induced oxidative stress in rats. Int J Biol Macromol 49: 942-947, 2011.

41. Kim H, Stote KS, Behall KM, Spears K, Vinyard B and Conway JM: Glucose and insulin responses to whole grain breakfasts varying in soluble fiber, beta-glucan: a dose response study in obese women with increased risk for insulin resistance. Eur J Nutr 48: 170-175, 2009.

42. Chen X, Bai X, Liu Y, et al: Anti-diabetic effects of water extract and crude polysaccharides from tuberous root of Liriope spicata var. prolifera in mice. J Ethnopharmacol 12: 205-209, 2009. 